\title{
Preanestezik değerlendirmede hastaların anestezi uygulamalarına ilişkin bilgi, deneyim ve kaygıları ile ilgili anket çalışması
}

A questionnaire study related to patients' knowledge, experiences and concerns on anesthesiology practice in preanesthetic evaluation

\author{
Tuba Kuvvet Yoldaş ${ }^{1} \quad$ Mehmet Yoldaş $^{2}$ Sinem Karagöz ${ }^{1} \quad$ Aylin Çakır Güven ${ }^{1}$ Yakup Çelik ${ }^{1}$ \\ Mehmet Kızılkaya $^{1}$ Sıtkı Ün ${ }^{3}$ Hilmi Güngör ${ }^{4}$ \\ ${ }^{1}$ Katip Çelebi Üniversitesi Atatürk Eğitim Araştırma Hastanesi, Anesteziyoloji ve Reanimasyon Kliniği, \\ İzmir, Türkiye \\ ${ }^{2}$ Tepecik Eğitim ve Araştırma Hastanesi, Üroloji Kliniği, İzmir, Türkiye \\ ${ }^{3}$ Katip Çelebi Üniversitesi Atatürk Eğitim Araştırma Hastanesi, Üroloji Kliniği, İzmir, Türkiye \\ ${ }^{4}$ Bozyaka Eğitim ve Araştırma Hastanesi, Genel Cerrahi Kliniği, İzmir, Türkiye
}

\section{Öz}

Amaç: Anestezi ve anestezi doktoru, toplum tarafından daha tanınır hale gelmeye başlamıştır. Bu çalışmada operasyon, ağrı tedavisi veya sedasyon için anestezi polikliniğine başvuran hastalara anestezi ve anestezi doktoru ile ilgili bilgilerini, deneyimlerini ve kaygılarını belirlemek amacıyla bir anket hazırlandı.

Gereç ve Yöntem: Katip Çelebi Üniversitesi Atatürk Eğitim Araştırma Hastanesi, anesteziyoloji polikliniğine başvuran 18-90 yaş arasındaki 249 hastaya yaş, cinsiyet, eğitim durumu, meslek gibi demografik bilgiler, önceki anestezi deneyimi, alerji öyküsü, anestezi yöntemleri ile ilgili bilgileri, anestezi doktorunun görevleri ile ilgili bilgileri ve anestezi ile ilgili korkuları içeren, 20 sorudan oluşan anket uygulandı.

Bulgular: Olguların eğitim durumunda en fazla yüzdeyi \%26.1 ile ilkokul mezunları oluşturuyordu. Anestezi deneyimi olanlar olguların \%44.6'sı idi. Olguların \%48.2'si anestezinin uzman doktor tarafından uygulandığını biliyordu. Anestezi ile ilgili korkular sorgulandığında en fazla olguların \%29.3'ü ile "öleceğim" cevabı verildi.

Sonuç: Anestezi doktoru ve anestezi ile ilgili sorulara verilen doğru cevaplar ile anestezi deneyimi ve eğitim düzeyi (lise, üniversite) arasında istatistiksel olarak anlamlı ilişki mevcuttu. Eğitim düzeyi yükseldikçe olguların anestezi konusundaki bilgilerinin arttığı sonucuna varıldı.

Anahtar Sözcükler: Anesteziyoloji, anket, bilgi.

\section{Abstract}

Aim: Public interest in anesthesia and anesthesiologist is increasing. In this study a questionnaire was set up to reveal patients' knowledge who were consulted anesthesia clinic for sedation, analgesia or anesthesia about the role of an anesthesiologist and their concern about anesthesia.

Materials and Methods: Two hundred and forty-nine patients, aged between 18-90, who were referred to Anesthesia Outpatient Clinic of Katip Çelebi University Atatürk Education and Research Hospital, were requested to fill out a questionnaire consisting of 20 questions related to age, sex, education, occupation, anesthesia history, allergy history, methods of anesthesia, working place of anesthesiologist, anxieties related to anesthesia.

Results: Questions related to education level of patients showed that $26.1 \%$ of them had primary education. The rate of patients who had experienced anesthesia were $44.6 \%$. The $48.2 \%$ of the patients knew the anesthesia administered by a physician specialist. The question related to fear of anesthesia was mostly answered as "I will die" by $29.3 \%$ of patients.

Conclusion: Statistically significant relation was found between level of education (high school, university) and anesthesia experience of patients with correct answers about anesthesiology and anesthesiologist. It is concluded that the higher the education level of patients, the more knowledge about anesthesia.

Keywords: Anesthesiology, survey, knowledge.

\footnotetext{
Yazışma Adresi: Tuba Kuvvet Yoldaş

Katip Çelebi Üniversitesi Atatürk Eğitim Araştırma Hastanesi,

Anesteziyoloji ve Reanimasyon Kliniği, İzmir, Türkiye

Geliş Tarihi: 15.01.2015 Kabul Tarihi: 10.06.2015
} 


\section{Giriş}

Günümüzde toplumumuzun tıbbi konulara olan ilgisi artmaktadır (1). Ancak birçok kişi, anestezi uygulamaları ve anestezi doktorunun hastanede çeşitli alanlardaki rolü ile ilgili yeterince bilgiye sahip değildir. Toplumun anestezi doktoru ile ilgili bilgisi oldukça azdır, hatta birçok kişi anestezi doktorunun tıp doktoru olduğunu dahi bilmemektedir (2). Anestezi doktorları sıklıkla tanınmayan doktorlardır (3). Bu, operasyon planlanan hastaların kısa süre önce hastaneye çağırılması ve karmaşık bir ortama maruz kalmaları gerçeğine bağlanabilir (4). Hastaların birçoğu, çok fazla hastane personeli ile karşılaştıkları için operasyon öncesi anestezi doktoru ile karşılaştığını hatırlamaz (5). Yapılan çalışmalar hastaların, anestezi doktorunun eğitim durumunu bilmediklerini (6), operasyon salonunda anestezi doktorunun ne yaptığının farkında olmadıklarını veya cerrah ile nasıl bir görev paylaşımı içinde olduğunu bilmediklerini göstermiştir (1).

Tablo-1. Hastaların Anestezi ile İlgili Bilgilerini Değerlendiren Anket Soruları.

\section{ANESTEZI POLIKLINIĞi ANKET FORMU (BIRDEN FAZLA ŞIKKI IŞARETLEYEBiLIRSINIZ)}

$\mathrm{Bu}$ anket sizlere anesteziyi tanıtmak ve anestezi hakkındaki bilgilerinizi değerlendirmek için yapılmaktadır.

Tarih ...............

1. Cinsiyetiniz: $\quad \square$ Kadın $\square$ Erkek

2. Yaşını:

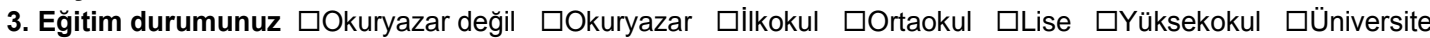

4. Mesleğiniz:

5. Daha önce narkozla (anestezi ile) ameliyat oldunuz mu?

口Evet $\square$ Hayır

6. Herhangi bir ilaca alerjiniz var mı? $\square$ Var $\quad \square$ Yok $\square$ Bilmiyorum

7. Anestezi polikliniğine neden geldiniz?

$\square$ Ameliyat öncesi hastalıklarımla ile ilgili bilgi vermeye $\square$ Kullandığım ilaçları söylemeye $\square$ Ağrım olduğu için

$\square$ Daha önce geçirdiğim ameliyatları, bunlar sırasındaki narkoz bilgilerini vermeye $\square$ Hepsi $\square$ Bilmiyorum

8.Anestezi sizce tüm hastalara aynı yöntemle mi uygulanır? $\quad \square$ Evet $\quad \square$ Hayır $\quad \square$ Bilmiyorum

9.Anesteziden önce;

$\square$ Sadece katı yiyecekler yenmemelidir. $\square$ Sadece sıvı içecekler içilmemelidir. $\square$ Hem katı hem sıvı besinler yenmemelidir.

$\square \mathrm{Az}$ az yiyecek yenebilir. $\square$ Hiçbir şeyin kesilmesine gerek yoktur.

10.Ameliyattan önce tansiyon yüksekliği, kalp rahatsızlığı, şeker hastalığı gibi ek hastalıklar belirtilmeli midir?

$\square$ Evet $\square$ Hayır $\square$ Bilmiyorum

11. Ameliyat gerektiğinde anestezi uygulanır mı? $\quad \square$ Evet $\quad \square$ Hayır $\square$ Bilmiyorum

12.Anestezi uygulaması nasıl yapılır?

口Damardan ilaç verilerek $\square$ Gaz koklatılarak $\square$ Sadece ameliyat bölgesini uyuşturarak $\quad \square$ Her üçü de uygulanabilir

$\square$ Bilgim yok

13.Aşağıdaki hangi anestezi yöntemlerini biliyorsunuz?

$\square$ Genel anestezi $\square$ Lokal anestezi $\square$ Bölgesel anestezi $\square$ Hepsi $\square$ Hiçbiri

14. Sizce anestezi doktoru nerede çalışır?

$\square$ Poliklinik $\square$ Ameliyathane $\square$ Yoğun bakım $\square$ Ağrı tedavisi $\square$ Böbrek taşı kırdırma (ESWL), endoskopi laboratuvarı (kolonoskopi, ERCP, hortumla mideye, bağırsağa bakma), kateter anjiyografi laboratuvarı, radyolojik görüntüleme (tomografi çekimi, opak madde alerjisi) $\square$ Hiçbirini bilmiyorum $\square$ Hepsi

15. Anestezi doktorunun ameliyatta neler yaptığını biliyor musunuz?

$\square$ Hastanın ağı duymamasını sağlar $\square$ Uyuma ve uyanıklığı yani bilinç durumunu takip eder $\square$ Kan basıncını takip eder

$\square$ Kalp hızını takip eder $\square$ Kandaki oksijen miktarını takip eder $\square$ Sıvı ve kan kaybını karşılar $\square$ Hiçbirini bilmiyorum

$\square$ Hepsini yapar

16. Anestezinin kimin tarafından verildiğini düşünüyorsunuz?

口Uzman hekim $\square$ Pratisyen hekim $\square$ Hemşire 口Teknisyen $\square$ Sağlık memuru $\square$ Bilgim yok

17. Anesteziniz hakkında size kim bilgi vermeli?

$\square$ Cerrah $\square$ Anestezi doktoru $\square$ Hemşire / teknisyen

18. Anesteziden korkuyor musunuz? $\square$ Evet $\square$ Hayır

19. Anestezi işlemi ile ilgili korkularınız nelerdir?

$\square$ Ağı duyacağım $\square$ Bulantım kusmam olacak $\square$ Anesteziden uyanamayacağım $\square$ Çevreyi tanıyamayacağım

$\square$ Boğazım ağrıyacak $\square$ Ameliyatta tam uyuyamayacağım $\square$ Bilincimi kaybedip istemediğim şeyler söyleyeceğim

$\square$ Öleceğim $\square$ Herhangi bir korkum yok

20. Postoperatif ağrı;

$\square$ Normal bir durumdur, tolere edilebilir. $\square$ lìileşmenin bir göstergesidir. $\square$ Ağrı kesici ilaç kullanılmalıdır.

$\square$ Dayanılmaz bir durumdur, ağrımın kesilmesini isterim. 
Preoperatif anestezi bakısı, operasyon için hastayı değerlendirmeye ek olarak hastaya, anestezi uygulamaları ve anestezi doktorunun rolü hakkında bilgi vermesi açısından önemlidir (4). Hastalar sıklıkla genel, rejyonel anestezi ve operasyonla ilgili kaygılar taşır $(7,8)$. Cerrahi girişim planlanan hastalar kendi güvenliği, operasyon sonucu ve konforlarıyla ilgili endişelerini ifade etmektedirler (9). Bütün tıbbi girişimler risk taşımaktadır ancak hastalar sıklıkla anesteziyi en riskli girişim olarak düşünürler. Hastaların birçoğu ameliyattan sonra uyanamayacakları veya ameliyat sırasında uyanabilecekleri gibi düşüncelerden dolayı kaygılıdırlar. Anestezi öncesi hastaların bilgilendirilmesi korku ve anksiyeteye bağlı oluşan morbiditeyi azaltmakta ve hasta memnuniyetini arttırmaktadır $(10,11)$.

Bu çalışma; operasyon, ağrı tedavisi veya sedasyon için anestezi polikliniğine başvuran hastalara anestezi ve anestezi doktoru ile ilgili bilgilerini, deneyimlerini ve kaygılarını belirlemek amacıyla planlanmış bir anket çalışmasıdır.

\section{Gereç ve Yöntem}

Yerel etik kurul onayı alındıktan sonra Ağustos-Kasım 2014 tarihleri arasında Katip Çelebi Üniversitesi Atatürk Eğitim Araştırma Hastanesi anestezi polikliniğine başvuran hastalar çalışma için değerlendirildi. Çalışmaya katılacak hastalar, yapılacak incelemeler konusunda bilgilendirildi, her hastaya, gönüllü katıldıklarına ilişkin onay formu okutuldu ve imzası olan hastalar çalışmaya alındı. Operasyon öncesi değerlendirme, sedasyon veya ağrı tedavisi için anestezi polikliniğine başvuran hastaların anestezi hakkındaki bilgilerini ölçmek için yaş, cinsiyet, eğitim durumu, meslek, önceki anestezi deneyimi ve alerji öyküsü soruları ve birden fazla seçeneğin işaretlenebildiği çoktan seçmeli anestezi ile ilgili sorular soruldu. Hastaların anestezi doktorunun işlevleri, görev yerleri, anestezi yöntemleri hakkındaki bilgileri ve endişeleri sorgulandı. Anket soruları hastanemizdeki uygulamalara ve benzer anket çalışmalarının verilerinden yararlanılarak $(2,4,9)$ oluşturuldu (Tablo- 1$)$. Hastalardan 20 sorudan oluşan anketi doldurmaları istendi.

Örneklem sayısını tespit etmek için GPower 3.1 programı kullanıldı. Etki gücü 0.5 alınarak hesaplanan örneklem sayısı 80 olarak bulundu. Hastanemiz polikliniğine başvuran olgu sayısı oldukça yüksek olduğu için 18-90 yaş arasındaki 250 hasta çalışmaya alındı. Türkçe bilmeyen, mental durum bozukluğu olan hastalar çalışma dışı bırakıldı. Sadece bir hasta sorulara net cevap veremediği için çalışmaya dahil edilmedi. Okuryazar olmayan hastalara anestezi doktoru soruları sordu ve kaydetti. Diğer hastalar anket sorularını kendileri okuyup doldurdu. 20 sorudan oluşan ankette yaş, cinsiyet, eğitim durumu, meslek gibi demografik bilgiler, önceki anestezi deneyimi, alerji öyküsü, anestezi yöntemleri ile ilgili bilgileri, anestezi doktorunun görevleri ile ilgili bilgileri ve anestezi ile ilgili korkuları soruldu.
Verilerin istatistiksel analizi IBM SPSS Statics Version 22 paket programında \%95 güvenle yapıldı. Yaş değişkeni normal dağılmadığından (Kolmogorov-Smirnov $\mathrm{p}<0.05)$ erkek ve kadınların yaşlarının karşılaştırılmasında Mann Whitney $U$, kategorik değişkenlerin gruplar arasında karşılaştırılmasında Pearson chi-square, Fisher's exact test ve Ki-kare trend istatistiksel analizleri kullanıldı. $p<0.05$ değerleri, istatistiksel olarak anlamlı kabul edildi.

\section{Bulgular}

Hastanemiz Anesteziyoloji ve Reanimasyon polikliniğine başvuran 250 olgunun 249'u çalışmaya alındı. İki yüz kırk dokuz olgunun 121'i kadın (\%48.6), 128'i erkek (\%51.4) idi. Olguların \%23.7'si $18-30$ yaş, \%65.5'i 30-60 yaş, \%10.8'i 60 yaş üstüydü. İncelemeye alınan kadın ve erkek olguların yaş ortalamaları arasında istatistiksel olarak anlamlı fark bulunmadı. Ankete katılanların \%3.2'si okur-yazar değil, \%7.2 okur-yazar, \%26.1'i ilkokul, \%20.5'i ortaokul, \%17.3'ü lise, \%11.2'si yüksekokul, \%14.5'i üniversite mezunuydu. Ankete katılanların çoğunluğunu (\%27.3) ev hanımları oluşturuyordu (Tablo-2).

Tablo-2. Sosyo-demografik Özellikler.

\begin{tabular}{|c|c|c|c|}
\hline & & $\mathrm{n}$ & $\%$ \\
\hline \multirow{2}{*}{ Cinsiyet } & Kadın & 121 & 48.6 \\
\hline & Erkek & 128 & 51.4 \\
\hline \multirow{3}{*}{ Yaş } & 30 yaş ve altı & 59 & 23.7 \\
\hline & $31-60$ yaş & 163 & 65,5 \\
\hline & 60 yaş üzeri & 27 & 10.8 \\
\hline \multirow{7}{*}{ Eğitim Durumu } & Okur-yazar değil & 8 & 3.2 \\
\hline & Okur-yazar & 18 & 7.2 \\
\hline & İlkokul & 65 & 26.1 \\
\hline & Ortaokul & 51 & 20.5 \\
\hline & Lise & 43 & 17.3 \\
\hline & Yüksekokul & 28 & 11.2 \\
\hline & Üniversite & 36 & 14.5 \\
\hline \multirow{2}{*}{ Eğitim } & Lise altı & 142 & 57.0 \\
\hline & Lise ve üzeri & 107 & 43.0 \\
\hline \multirow{8}{*}{ Meslek } & Serbest & 33 & 13.3 \\
\hline & Ev hanımı & 68 & 27.3 \\
\hline & Öğrenci & 31 & 12.4 \\
\hline & İşçi & 37 & 14.9 \\
\hline & Memur & 46 & 18.5 \\
\hline & Emekli & 16 & 6.4 \\
\hline & Çiftçi & 12 & 4.8 \\
\hline & İşsiz & 6 & 2.4 \\
\hline
\end{tabular}

Daha önce anestezi deneyimi olanlar olguların \%44.6'sı iken, anestezi deneyimi olmayanlar olguların \%55.4 idi. Herhangi bir ilaç alerjisi olmayanlar olguların \%75.9'u, ilaç alerjisini bilmeyenler ise olguların \%18.1 idi (Tablo-3). 
Tablo-3. Anestezi İle İlgili Bilgilerin Dağııımı.

\begin{tabular}{|c|c|c|c|}
\hline & & $\mathbf{n}$ & $\%$ \\
\hline \multirow{2}{*}{$\begin{array}{l}\text { Daha önce anestezi ile ameliyat } \\
\text { oldunuz mu? }\end{array}$} & Evet & 111 & 44.6 \\
\hline & Hayır & 138 & 55.4 \\
\hline \multirow[t]{3}{*}{ İlaç alerjiniz var mı? } & Var & 15 & 6.0 \\
\hline & Yok & 189 & 75.9 \\
\hline & Bilmiyorum & 45 & 18.1 \\
\hline \multirow[t]{6}{*}{ Anestezi polikliniğine neden geldiniz? } & Ameliyat öncesi hastalıklarımla ile ilgili bilgi vermeye & 122 & 49.0 \\
\hline & Kullandığım ilaçları söylemeye & 10 & 4.0 \\
\hline & Ağrım olduğu için & 23 & 9.2 \\
\hline & $\begin{array}{l}\text { Daha önce geçirdiğim ameliyatları, bunlar sırasındaki narkoz } \\
\text { bilgilerini vermeye }\end{array}$ & 8 & 3.2 \\
\hline & Hepsi & 44 & 17.7 \\
\hline & Bilmiyorum & 42 & 16.9 \\
\hline \multirow{3}{*}{$\begin{array}{l}\text { Anestezi tüm hastalara aynı yöntemle } \\
\text { mi uygulanır? }\end{array}$} & Evet & 37 & 14.8 \\
\hline & Hayır & 95 & 38.2 \\
\hline & Bilmiyorum & 117 & 47.0 \\
\hline \multirow[t]{5}{*}{ Anesteziden önce } & Sadece katı yiyecekler yenmemelidir. & 24 & 9.6 \\
\hline & Sadece sıvı içecekler içilmemelidir. & 22 & 8.8 \\
\hline & Hem katı hem sıvı besinler yenmemelidir. & 159 & 63.9 \\
\hline & Az az yiyecek yenebilir. & 16 & 6.4 \\
\hline & Hiçbir şeyin kesilmesine gerek yoktur. & 28 & 11.2 \\
\hline \multirow{2}{*}{$\begin{array}{l}\text { Ameliyattan önce kronik hastalıklar } \\
\text { belirtilmelidir }\end{array}$} & Doğru & 208 & 83.5 \\
\hline & Yanlış/Bilmiyor & 41 & 16.5 \\
\hline \multirow{3}{*}{$\begin{array}{l}\text { Ameliyat gerektiğinde anestezi gerekir } \\
\text { mi? }\end{array}$} & Evet & 198 & 79.5 \\
\hline & Hayır & 14 & 5.6 \\
\hline & Bilmiyorum & 37 & 14.9 \\
\hline \multirow[t]{5}{*}{ Anestezi uygulaması nasıl yapılır? } & Damardan ilaç verilerek & 39 & 15.7 \\
\hline & Gaz koklatılarak & 11 & 4.4 \\
\hline & Sadece ameliyat bölgesini uyuşturarak & 11 & 4.4 \\
\hline & Her üçü de uygulanabilir & 88 & 35.3 \\
\hline & Bilgim yok & 100 & 40.2 \\
\hline \multirow{5}{*}{$\begin{array}{l}\text { Hangi anestezi yöntemlerini } \\
\text { biliyorsunuz? }\end{array}$} & Genel anestezi & 28 & 11.2 \\
\hline & Lokal anestezi & 23 & 9.2 \\
\hline & Bölgesel anestezi & 4 & 1.6 \\
\hline & Hepsi & 132 & 53.0 \\
\hline & Hiçbiri & 62 & 24.9 \\
\hline
\end{tabular}

Ankete katılanların anestezi ile ilgili bilgi düzeylerini ölçmek için çeşitli sorular soruldu. Anestezi polikliniğine gelme nedenini bilmeme oranı \%16.9 idi. Doğru cevap olan "Hepsi" seçeneğini işaretleyenler olguların \%17.7'si idi. "Bilmiyorum" veya "Hepsi" seçenekleri dışındaki seçeneklerden bir veya daha fazlasını işaretleyenler eksik işaretleme olarak kabul edildi ve oranı \%65.4 idi. Olguları eğitim düzeyine göre lise altı ve lise-lise üstü olarak iki gruba ayırdığımızda olguların bu soruya doğru cevabı vermeleri ile eğitim düzeyi arasında anlamlı ilişki bulunmadı ( $p=0.299$ ). Daha önce anestezi deneyimi olan olguların anestezi polikliniğine gelme nedenine doğru cevabı vermeleri arasında anlamlı ilişki bulunmadı $(p=0.072)$. "Anestezi aynı yöntemle mi uygulanır?" sorusuna olguların \%38.2'si "hayır" cevabını verdi. Bu soruya verilen doğru cevabın eğitim düzeyi ile ilişkisi anlamlı bulundu $(p=0.016)$. Anestezi deneyimi ile de bu soruya doğru cevap verme arasında anlamlı ilişki bulundu ( $p=0.002)$. "Ameliyattan önce kronik hastalık belirtilmeli midir?" sorusuna olguların \%83.5'i "Evet" cevabını verdi. Bu soruya verilen doğru cevabın hem eğitim düzeyi ile hem de anestezi deneyimi ile ilişkili olduğu görüldü $(p=0.003)(p=0.0012)$. Ameliyat öncesi katı ve sıvı besinlerin kesilmesi gerektiğini olguların $\% 63.9$ 'u biliyordu. Ameliyattan önce oral alımla ilgili soruya doğru cevabın verilmesi eğitim düzeyi ile ilişkili iken anestezi deneyimi ile ilişkili bulunmadı $(p=0.001)$ $(p=0.766)$. Anestezi yöntemleri iki ayrı soru ile 
sorgulandı. İlk soruda anlaşılabilir şekilde anestezi yöntemleri açıklandı ve bu soruya verilen cevabın eğitim düzeyi ile ilişkisi anlamlı bulundu ( $p=0.023)$. Daha önce anestezi deneyimi olanlarda ise anestezi yöntemini bilme arasında anlamlı ilişki bulunmadı $(p=0.637)$. Genel, bölgesel, lokal anestezi gibi tıbbi terimler kullanılarak sorgulandığında ise soruya doğru cevap verme, eğitim düzeyinin artması ve anestezi deneyiminin olmasıyla anlamlı ilişkili bulundu $(p=0.005)(p=0.001)$. "Anestezi doktoru nerede çalışır?" sorusunda olguların \%57'si anestezi doktorunun tüm çalışma yerlerini bilirken sadece ameliyathane cevabını verenler olguların \%27.3'ü idi. Eğitim düzeyi arttıkça anestezi doktorunun nerede çalıştığını bilme düzeyi anlamlı olarak artıyordu $(p=0.001)$. Aynı şekilde anestezi deneyimi olan olgularda da bu soruya verilen doğru cevap anlamlı yüksekti $(p=0.001)$. "Anesteziyi kim verir?" sorusuna "uzman hekim" cevabını verenler olguların \% 48.2'si , "anestezi teknisyeni” cevabını verenler olguların \%13'ü idi. Anestezi deneyimi ile bu soruya verilen cevabın ilişkisi anlamlı ( $p=0.001$ ) bulunurken eğitim düzeyi ile anlamlı ilişki bulunmadı $(p=0.12)$. "Anestezi hakkında bilgiyi kim vermelidir?" sorusuna \%89.2 hasta "anestezi uzmanı" olarak cevap verdi. Eğitim düzeyinin artması ile bu soruya verilen doğru cevap arasında anlamlı ilişki bulundu $(p=0.048)$. Anestezi uzmanının operasyon sırasındaki görevleri ile ilgili sorulan soruya "bilmiyorum" cevabını verenler olguların \%20.1 idi. Anestezi doktorunun tüm görevlerini bilenler ise $\% 53$ idi. Bu soruya verilen doğru cevaplar, anestezi deneyimi ve eğitim düzeyi ile anlamlı ilişkili bulundu ( $p=0.001) \quad(p=0.001)$. SPSS programında yaptığımız ortalama yaş hesaplaması 42 olması üzerine olguları 45 yaş altı ve 45 yaş üstü olarak ayırdık. Yaş gruplarına göre anestezi personeli bilgileri dağılımı incelendiğinde; anestezi doktorunun nerede çalıştığı bilgileri açısından gruplar arasında istatistiksel olarak anlamlı fark bulundu $(p=0.005)$. Anestezi doktorunun ameliyatta neler yaptığı bilgileri açısından gruplar arasında istatistiksel olarak anlamlı fark bulunmadı $(p=0.576)$. Anestezinin kimin tarafından verildiği ve anestezi hakkında kimin bilgi vereceği bilgileri açısından gruplar arasında istatistiksel olarak anlamlı fark bulundu $(p=0.033) \quad(p=0.082)$ (Tablo-6). Anestezi uygulamaları, anestezi doktorunun görevi ile ilgili sorularla eğitim durumu ve anestezi deneyimi ilişkisi Tablo-3, Tablo-4 ve Tablo-5'de verilmiştir.

Tablo-4. Olguların Eğitim Durumlarına Göre Anestezi Bilgileri Dağılımı.

\begin{tabular}{|c|c|c|c|c|c|c|c|c|}
\hline & & \multicolumn{4}{|c|}{ Eğitim } & \multirow{2}{*}{\multicolumn{2}{|c|}{ Toplam }} & \multirow{3}{*}{$\mathbf{p}$} \\
\hline & & \multicolumn{2}{|c|}{ Lise altı } & \multicolumn{2}{|c|}{ Lise ve üzeri } & & & \\
\hline & & $\mathbf{n}$ & $\%$ & $\mathbf{n}$ & $\%$ & $\mathbf{n}$ & $\%$ & \\
\hline \multirow{2}{*}{$\begin{array}{l}\text { Anestezi polikliniğine neden } \\
\text { geldiniz? }\end{array}$} & Doğru & 22 & 15.5 & 22 & 20.6 & 44 & 17.7 & \multirow{2}{*}{0.299} \\
\hline & Eksik/Bilmiyor & 120 & 84.5 & 85 & 79.4 & 205 & 82.3 & \\
\hline \multirow{2}{*}{$\begin{array}{l}\text { Anestezi tüm hastalara aynı } \\
\text { yöntemle mi uygulanır? }\end{array}$} & Doğru & 45 & 31.7 & 50 & 46.7 & 95 & 38.2 & \multirow{2}{*}{0.016} \\
\hline & Yanlış/Bilmiyor & 97 & 68.3 & 57 & 53.3 & 154 & 61.8 & \\
\hline \multirow{2}{*}{$\begin{array}{l}\text { Anesteziden önce yiyecek- } \\
\text { içecek tüketimi bilgisi }\end{array}$} & Doğru & 76 & 53.5 & 83 & 77.6 & 159 & 63.9 & \multirow{2}{*}{0.001} \\
\hline & Eksik/Bilmiyor & 66 & 46.5 & 24 & 22.4 & 90 & 36.1 & \\
\hline \multirow{2}{*}{$\begin{array}{l}\text { Ameliyattan önce kronik } \\
\text { hastalıklar belirtilmelidir }\end{array}$} & Doğru & 110 & 77.5 & 98 & 91.6 & 208 & 83.5 & \multirow{2}{*}{0.003} \\
\hline & Yanlış/Bilmiyor & 32 & 22.5 & 9 & 8.4 & 41 & 16.5 & \\
\hline \multirow{3}{*}{$\begin{array}{l}\text { Ameliyat gerektiğinde anestezi } \\
\text { gerekir mi? }\end{array}$} & Evet & 111 & 78.2 & 87 & 81.3 & 198 & 79.5 & \multirow{3}{*}{0.001} \\
\hline & Hayır & 2 & 1.4 & 12 & 11.2 & 14 & 5.6 & \\
\hline & Bilmiyorum & 29 & 20.4 & 8 & 7.5 & 37 & 14.9 & \\
\hline \multirow{5}{*}{$\begin{array}{l}\text { Anestezi uygulaması nasıl } \\
\text { yapılır? }\end{array}$} & Damardan ilaç verilerek & 22 & 15.5 & 17 & 15.9 & 39 & 15.7 & \multirow{5}{*}{0.023} \\
\hline & Gaz koklatılarak & 7 & 4.9 & 4 & 3.7 & 11 & 4.4 & \\
\hline & $\begin{array}{l}\text { Sadece ameliyat bölgesini } \\
\text { uyuşturarak }\end{array}$ & 9 & 6.3 & 2 & 1.9 & 11 & 4.4 & \\
\hline & Her üçü de uygulanabilir & 39 & 27.5 & 49 & 45.8 & 88 & 35.3 & \\
\hline & Bilgim yok & 65 & 45.8 & 35 & 32.7 & 100 & 40.2 & \\
\hline \multirow{5}{*}{$\begin{array}{l}\text { Hangi anestezi yöntemlerini } \\
\text { biliyorsunuz? }\end{array}$} & Genel anestezi & 20 & 14.1 & 8 & 7.5 & 28 & 11.2 & \multirow{5}{*}{0.005} \\
\hline & Lokal anestezi & 13 & 9.2 & 10 & 9.3 & 23 & 9.2 & \\
\hline & Bölgesel anestezi & 4 & 2.8 & 0 & 0 & 4 & 1.6 & \\
\hline & Hepsi & 62 & 43.7 & 70 & 65.4 & 132 & 53 & \\
\hline & Hiçbiri & 43 & 30.3 & 19 & 17.8 & 62 & 24.9 & \\
\hline
\end{tabular}


Tablo-5. Olguların Anestezi Deneyimlerine Göre Anestezi Bilgileri Dağılımı.

\begin{tabular}{|c|c|c|c|c|c|c|c|c|}
\hline & & \multicolumn{4}{|c|}{$\begin{array}{l}\text { Daha önce anestezi ile } \\
\text { ameliyat oldunuz mu? }\end{array}$} & \multirow{2}{*}{\multicolumn{2}{|c|}{ Toplam }} & \multirow{3}{*}{ p } \\
\hline & & \multicolumn{2}{|c|}{ Evet } & \multicolumn{2}{|c|}{ Hayır } & & & \\
\hline & & $\mathbf{n}$ & $\%$ & $\mathbf{n}$ & $\%$ & $\mathbf{n}$ & $\%$ & \\
\hline \multirow{2}{*}{ Anestezi polikliniğine neden geldiniz? } & Doğru & 25 & 22.5 & 19 & 13.8 & 44 & 17.7 & \multirow{2}{*}{0.072} \\
\hline & Eksik/Bilmiyor & 86 & 77.5 & 119 & 86.2 & 205 & 82.3 & \\
\hline \multirow{2}{*}{$\begin{array}{l}\text { Anestezi tüm hastalara aynı yöntemle } \\
\text { mi uygulanır? }\end{array}$} & Doğru & 54 & 48.6 & 41 & 29.7 & 95 & 38.2 & \multirow{2}{*}{0.002} \\
\hline & Yanlış/Bilmiyor & 57 & 51.4 & 97 & 70.3 & 154 & 61.8 & \\
\hline \multirow{2}{*}{$\begin{array}{l}\text { Anesteziden önce yiyecek-içecek } \\
\text { tüketimi bilgisi }\end{array}$} & Doğru & 72 & 64.9 & 87 & 63 & 159 & 63.9 & \multirow{2}{*}{0.766} \\
\hline & Eksik/Bilmiyor & 39 & 35.1 & 51 & 37 & 90 & 36.1 & \\
\hline \multirow{2}{*}{$\begin{array}{l}\text { Ameliyattan önce kronik hastalıklar } \\
\text { belirtilmelidir? }\end{array}$} & Doğru & 100 & 90.1 & 108 & 78.3 & 208 & 83.5 & \multirow{2}{*}{0.012} \\
\hline & Yanlış/Bilmiyor & 11 & 9.9 & 30 & 21.7 & 41 & 16.5 & \\
\hline \multirow{2}{*}{$\begin{array}{l}\text { Ameliyat gerektiğinde anestezi } \\
\text { gerekir mi? }\end{array}$} & Evet & 101 & 91 & 97 & 70.3 & 198 & 79.5 & \multirow{2}{*}{0.001} \\
\hline & Hayır /Bilmiyor & 10 & 9 & 41 & 29.7 & 14 & 5.6 & \\
\hline \multirow{2}{*}{ Anestezi uygulaması nasıl yapılır? } & Biliyor & 41 & 36.9 & 47 & 34.1 & 88 & 35.3 & \multirow{2}{*}{0.637} \\
\hline & Eksik/Bilmiyor & 70 & 63.1 & 91 & 65.9 & 161 & 64.7 & \\
\hline \multirow{2}{*}{$\begin{array}{l}\text { Hangi anestezi yöntemlerini } \\
\text { biliyorsunuz? }\end{array}$} & Biliyor & 72 & 64.9 & 60 & 43.5 & 132 & 53 & \multirow{2}{*}{0.001} \\
\hline & Eksik/Bilmiyor & 39 & 35.1 & 78 & 56.5 & 117 & 47 & \\
\hline
\end{tabular}

Tablo-6. Olguların Yaş Gruplarına Göre Anestezi Personeli Bilgileri Dağılımı.

\begin{tabular}{|c|c|c|c|c|c|c|c|c|}
\hline & & \multicolumn{4}{|c|}{ YAŞ } & \multirow{2}{*}{\multicolumn{2}{|c|}{ Toplam }} & \multirow{3}{*}{$\mathbf{p}^{*}$} \\
\hline & & \multicolumn{2}{|c|}{$<45$ yaş } & \multicolumn{2}{|c|}{$\begin{array}{l}45 \text { yaş ve } \\
\text { üzeri }\end{array}$} & & & \\
\hline & & $\mathbf{n}$ & $\%$ & $\mathbf{n}$ & $\%$ & $\mathbf{n}$ & $\%$ & \\
\hline \multirow{2}{*}{ Anestezi Doktoru Nerde Çalışır? } & Biliyor & 148 & 96.7 & 84 & 87.5 & 232 & 93.2 & \multirow{2}{*}{0.005} \\
\hline & Bilmiyor & 5 & 3.3 & 12 & 12.5 & 17 & 6.8 & \\
\hline \multirow{2}{*}{$\begin{array}{l}\text { Anestezi Doktoru Ameliyatta } \\
\text { Neler Yapar? }\end{array}$} & Biliyor & 124 & 81 & 75 & 78.1 & 199 & 79.9 & \multirow{2}{*}{0.576} \\
\hline & Bilmiyor & 29 & 19 & 21 & 21.9 & 50 & 20.1 & \\
\hline \multirow{2}{*}{$\begin{array}{l}\text { Anestezi Kim Tarafından } \\
\text { Verilir? }\end{array}$} & Biliyor & 102 & 66.7 & 51 & 53.1 & 153 & 61.4 & \multirow{2}{*}{0.033} \\
\hline & Bilmiyor & 51 & 33.3 & 45 & 46.9 & 96 & 38.6 & \\
\hline \multirow{2}{*}{$\begin{array}{l}\text { Anestezi Hakkında Kim Bilgi } \\
\text { Vermeli? }\end{array}$} & Cerrah & 5 & 3.5 & 8 & 8.8 & 13 & 5.5 & \multirow{2}{*}{0.082} \\
\hline & Anestezi doktoru & 139 & 96.5 & 83 & 91.2 & 222 & 94.5 & \\
\hline
\end{tabular}

${ }^{*}$ Pearson chi-square

Anestezi ile ilgili korkuları değerlendirildiğinde ilk iki sırayı olguların \%29.3'ünün "öleceğim" ve \%25.3'ünün "anesteziden uyanamayacağım" cevapları oluşturuyordu. Olguların \%20.5'i herhangi bir korkusu olmayanları oluşturmakta idi. Otuz yaş altı olgularda ağrı duyma ve postoperatif bulantı-kusma olacağı korkusu anlamlı yüksek idi $(p=0.001)(p=0.006)$. Hastaların postoperatif ağrı konusundaki fikirleri sorgulandığında da olguların \%29.7'si "normal bir durumdur, tolere edilebilir", \%34.1'i "dayanılmaz bir durum, ağrımın kesilmesini isterim" dedi. Erkekler kadınlara göre postoperatif ağrının normal bir durum olduğunu ve tolere edilebileceğini belirtmiştir ve istatistiksel olarak anlamlı bulunmuştur $(p=0.013)$. Kadınlar ağrı kesicilerin kullanılmasının gerektiğini daha fazla belirtmiş ve istatistiksel olarak anlamlı bulunmuştur $(p=0.039)$ (Tablo-7). 
Tablo-7. Olguların Cinsiyetlerine Göre Postoperatif Ağrı Bilgileri Dağılımı.

\begin{tabular}{|c|c|c|c|c|c|c|c|c|}
\hline & & \multicolumn{2}{|c|}{ Kadın } & \multicolumn{2}{|c|}{ Erkek } & \multicolumn{2}{|c|}{ Toplam } & \multirow{2}{*}{$\mathbf{p}$} \\
\hline & & $\mathbf{n}$ & $\%$ & $\mathbf{n}$ & $\%$ & $\mathbf{n}$ & $\%$ & \\
\hline \multirow{2}{*}{ Normal bir durumdur. Tolere edilebilir. } & Evet & 27 & 22.3 & 47 & 36.7 & 74 & 29.7 & \multirow{2}{*}{0.013} \\
\hline & Hayır & 94 & 77.7 & 81 & 63.3 & 175 & 70.3 & \\
\hline \multirow{2}{*}{ İyileşmenin bir göstergesidir. } & Evet & 20 & 16.5 & 14 & 10.9 & 34 & 13.7 & \multirow{2}{*}{0.199} \\
\hline & Hayır & 101 & 83.5 & 114 & 89.1 & 215 & 86.3 & \\
\hline \multirow{2}{*}{ Ağrı kesici ilaç kullanılmalıdır. } & Evet & 34 & 28.1 & 22 & 17.2 & 56 & 22.5 & \multirow{2}{*}{0.039} \\
\hline & Hayır & 87 & 71.9 & 106 & 82.8 & 193 & 77.5 & \\
\hline \multirow{2}{*}{$\begin{array}{l}\text { Dayanılmaz bir durum. Ağrımın kesilmesini } \\
\text { isterim. }\end{array}$} & Evet & 40 & 33.1 & 45 & 35.2 & 85 & 34.1 & \multirow{2}{*}{0.727} \\
\hline & Hayır & 81 & 66.9 & 83 & 64.8 & 164 & 65.9 & \\
\hline
\end{tabular}

\section{Tartışma}

Ülkemizde Anesteziyoloji ve Reanimasyon Anabilim Dalı resmi olarak 1956 yılında intisas dalı olmuştur. Hızla ilerleyen teknoloji ile birlikte gelişime oldukça açık bir bilim dalıdır. Toplum tarafından gün geçtikçe daha fazla bilinir hale gelmiştir. Bugüne kadar yapılmış, literatürde yer alan çalışmalarda hastaların anestezi uygulamalarını bilmedikleri ve anestezi doktorunu yeterince tanımadıkları saptanmıştır $(12,13)$.

$\mathrm{Bu}$ anket çalışmasında Katip Çelebi Üniversitesi Atatürk Eğitim Araştırma Hastanesi Anesteziyoloji ve Reanimasyon polikliniğine başvuran, yaşları 18 ile 90 arasında değişen 249 hastanın anestezi uygulamaları ve anestezi doktoru hakkındaki bilgileri sorgulandı. Çalışmamız anestezi polikliniğine gelen olguların anesteziyi araştırmış olabilecekleri göz önüne alınırsa toplumun genelini yansıtması açısından kısıtlı olabilir. Bu anket çalışmasında, kişilerin eğitim düzeyleri ve anestezi deneyimleri ile anestezi konusundaki bilgi düzeyleri arasında anlamlı ilişki saptandı. Özellikle kişilerin anestezi ile ilgili bilgi düzeylerini etkileyen önemli etkenlerden biri eğitim durumu idi. Eğitim düzeyi yükseldikçe olguların bilgi düzeyleri de yükseliyordu. Ayrıca daha önce anestezi deneyimi olanların anestezi uygulamaları ile ilgili bilgileri anlamlı olarak yüksekti.

Anestezi doktorunun kim olduğu ile ilgili çeşitli çalışmalar yapılmıştır. Klafta ve ark. (1) 1996'da yayınladıkları derlemede anestezistlerin doktor olduğunu bilme \%65$\% 78$ iken Gottschalk ve ark. (9), Tohmo ve ark. (14) ile Hariharan ve ark. (15) çalışmalarında ise bu oran \%5990 olarak bildirilmiştir. Aras ve ark. (16) çalışmasında anesteziyi uygulaması gereken kişinin uzman hekim olması gerektiğini bilme oranı $\% 40.2$ bulunurken ankete katılanların \%10'u teknisyen cevabını vermiştir. Çalışmamızda anesteziyi uygulayan kişinin kim olduğuna hastaların \%48.2'si anestezi uzmanı derken $\% 13$ 'ü teknisyen cevabını verdi. Bu oranlar ülkemiz için anestezinin teknisyen tarafından uygulandığı düşüncesinin değişmesi açısından iyi bir gelişmedir. Çoğu hasta, anestezi doktorunun yoğun bakım, ağrı tedavisi ve sedasyon uygulanan girişimsel işlemlerde çalıştığını bilmemektedir. Çalışmamızda olguların \%57'si anestezi doktorunun tüm çalışma yerlerini biliyordu. Bu oranlar eğitim düzeyi ve anestezi deneyimi ile ilişkili idi.

Hastaların birçoğu cerrahın intraoperatif sorumluluğunu abartma eğilimindedir. Gottschalk ve ark. (9), üç merkezli yaptıkları çalışmada intraoperatif kan transfüzyonu, antibiyotik uygulaması ve ağrı yönetiminin cerrah ile anestezistin ortak sorumluluğu olarak bilindiğini göstermiştir. McGaw ve ark. (17) yaptığı çalışmada ise hastaların \%10'u anestezi doktorunun operasyon sırasında vital bulguları takip ve gerektiğinde müdahale ettiğini bilmiştir. Çalışmamızda olguların \%54.6'sı vital bulgu takibin, \%63'ü ağrı kontrolünün, $\% 65.4$ 'ü bilinç takibinin ve \%55.8'i sıvı, kan transfüzyonunun anestezi doktoru tarafından yapıldığını biliyordu. Hem anestezi deneyimi olanların hem de eğitim düzeyi yüksek olanların bu konuda daha bilinçli olduğu saptandı. Hariharan ve ark. (15) çalışmasında uyanıklık izleminin $\% 75$, ağrı kontrolünün $\% 67.4$, vital bulgu izleminin \%62.8, transfüzyon işlemlerinin \%42.6 oranında bilindiğini bildirmiştir.

Anketimize katılan olguların \%43'ü lise ve üzeri eğitim düzeyine sahip olmalarına rağmen \%16.9'u kliniğimize neden başvurduğunu bilmemekteydi. Olguların böyle sınırlı bilgiye sahip olmaları Laffey ve ark. (18) yaptığı anket çalışmasında da saptanmıştır ve rutin medikal uygulamaların çoğu hasta için çok anlam ifade etmediğini bildirmişlerdir.

Çalışmamızda anestezi ile ilgili korkularda ölüm korkusu (\%29.3) ilk sıradaydı. Anesteziden uyanamama (\%25.3) ve ağrı duyma (\%20.9) ölüm korkusunu izlerken hastaların \% 20.5'i hiçbir korkusu olmadığını belirtti. Benzer şekilde Keleş ve ark. (19), 2005'te yaptığı çalışmada hastaların \%35'i "hiçbir korkum yok" derken ameliyat öncesi en sık korkuların anesteziden uyanamama ve ameliyat sonrası ağrı duyma olduğunu belirtmiştir. Osinaike ve ark. (20) yaptığı çalışmada da ölüm korkusu (\%82) ve postoperatif ağrı (\%75.5) en sık görülen korkular olarak bildirilmiştir. Genel nüfusta da 
anksiyetenin kadınlarda erkeklere oranla iki kat fazla görüldüğü bilinmektedir (21). Süren ve ark. (22) yaptığı çalışmada yaş arttıkça anestezi ile ilgili endişe düzeyinin azaldığı; kadınların erkeklere göre ameliyat öncesi daha fazla endişeli olduğu bildirilmiştir. Çalışmamızda anestezi korkuları açısından kadınlarda ameliyatta tam uyuyamama ve anestezi sonrası çevreyi tanıyamama korkusu erkeklere göre daha fazla iken diğer korkular açısından anlamlı fark bulunmadı. Ağrı duyma ve bulantı-kusma olacağı korkusu genç olgularda fazla iken diğer korkular açısından fark bulunmamakta idi.

Bilgilendirme, hastaların korku ve kaygılarını azaltırken memnuniyetlerini arttırmaktadır. Preanestezik vizitin, anestezi doktorunun kendini tanıtması, anestezi uygulamaları ile ilgili bilgilendirme, olası komplikasyonların anlatılması ve hastadan neler istenildiğinin açıklanması açısından oldukça önemli bir rolü vardır. Hastalarımızın \%89.6'sı anestezi ile ilgili bilgilendirmenin anestezi doktoru tarafından yapılmasını istedi. Eğer olgular bilgilendirilirse hem bilgi düzeyleri hem de memnuniyetleri artacaktır. Bu amaçla anestezi uzmanının bilgilendirmesi dışında broşürler, interaktif videolar ve medya araçları kullanılabilir. Bu şekilde toplumun anestezi hakkındaki bilgilerinin arttırılması sağlanabilir. Bilgilendirilmiş hastaların anestezi ile ilgili kaygı ve korkularının azalması ile postoperatif morbidite de azalacaktır

\section{Sonuç}

Anketimize katılan olguların anestezi ve anestezi doktoru ile ilgili bilgi düzeyi, eğitim seviyesi ve anestezi deneyimi ile ilişkilidir. Yapılacak preoperatif vizitler olguların bilgilenmesine katkı sağlayacaktır. Anestezi doktorlarının hastalara daha fazla bilgilendirme yapmasının yanı sıra küçük broşürler, videolar gibi görsel iletişim araçları ve yayın kuruluşlarının katkıları hastaların bilgilenmesinde önemli rol oynayacaktır.

\section{Kaynaklar}

1. Klafta JM, Roizen MF. Current knowledge of patients' attitudes toward and preparation for anesthesia: A review. Anesth Analg 1996;83(6):1314-21.

2. Demir A, Turan $S$, Balaban $F$ ve ark. Anestezi uygulamaları ile ilgili olarak preanestezik değerlendirme sırasında hastalarda yapılan anket çalışması. Türk Anest Der Dergisi 2009;37(4):225-33.

3. Hume MA, Kennedy B, Ashbury AJ. Patient knowledge of anaesthesia and perioperative care. Anaesthesia 1994;49(8):715-8.

4. JG Laffey, M Coleman, JF Boylan. Patients' knowledge of perioperative care. Ir J Med Sci 2000;169(2):113-8.

5. Sykes MK. Recognition of the anaesthetist (editorial). Anaesthesia 1995;50(5):381-2.

6. Calman LM, Mihalache A, Evron S, Ezri T. Current understanding of the patient's attitude toward the anesthetist's role and practice in Israel: Effect of the patient's experience. J Clin Anesth 2003;15(6):451-4.

7. Kindler $\mathrm{CH}$, Harms C, Amsler F, Ihde-Scholl T, Scheidegger D. The visual analog scale allows effective measurement of preoperative anxiety and detection of patients' anesthetic concerns. Anesth Analg 2000;90(3):706-12.

8. Matthey PW, Finegan BA, Finucane BT. The public's fears about and perceptions of regional anesthesia. Reg Anesth Pain Med 2004;29(2):96-101.

9. Gottschalk A, Seelen S, Tivey S. What do patients know about anesthesiologists? Results of a comparative survey in an U.S., Australian, and German university hospital. J Clin Anesth 2013;25(2):85-91.

10. Fischer SP. Development and effectiveness of an anesthesia preoperative evaluation clinic in a teaching hospital. Anesthesiology 1996;85(1):196-206.

11. Tanser SJ, Birt DJ. Who is watching over me?--was the public's perception of the anaesthetist changed by National Anaesthesia Day? J R Nav Med Serv 2000;86(3):134-41.

12. Şekerci S, Akpek E, Göktuğ A, ve ark. Hasta ve yakınları ile toplumun farklı kesimlerinin anestezi ve uygulamaları konusundaki bilgi ve davranışları. Anestezi Dergisi 2001;9:48-51.

13. Irita K, Takahashi S. Lack of communication between anesthesiologists and surgeons: Comparison of questionnaire survey among anesthesiologists with that among surgeons concerning pre-anesthetic evaluation of surgical patients. Masui 2000;49(1):7-17.

14. Tohmo $\mathrm{H}$, Pälve $\mathrm{H}$, Illman $\mathrm{H}$. The work, duties and prestige of Finnish anesthesiologists: Patients' view. Acta Anaesthesiol Scand 2003;47(6):664-6

15. Hariharan S, Merritt-Charles L, Chen D. Patient perception of the role of anesthesiologists: A perspective from the Caribbean. $J$ Clin Anesth 2006;18(7):504-9.

16. Aras D, Çil C, Akçaoğlu AC. Denizli ili Yenişehir Sağlık Ocağı bölgesinde halkın anesteziyoloji uygulamalarına ilişkin bilgi, tutum ve önceki anestezi deneyimleri. Pam Tıp Derg 2008;2(2):76-82.

17. McGaw CD, Hanna WJ. Knowledge and fears of anaesthesia and surgery. The Jamaican perspective. West Indian Med $J$ 1998;47(2):64-7.

18. Laffey JG, Coleman M, Boylan JF. Patients' knowledge of perioperative care. Ir J Med Sci 2000; 169(2):113-8.

19. Keleş GT, Toprak V, Kefi A. Postoeratif dönemde hastaların anestezi konusundaki endişeleri nelerdir? Türk Anest Rean Der Dergisi 2005;33:307-12.

20. Osinaike BB, Dairo MD, Oyebamiji EO, Odesanya JO, Tanimowo A. Attitude of general public to risks associated with anaesthesia. East Afr J Public Health 2007;4(1):40-2.

21. Öztürk O. Ruh sağlığı ve bozuklukları, Ankara: Hekimler Yay. Birliği; 1994:263(6):272-6.

22. Süren $M$, Karaman S, Doğru S. Ameliyat olan hastaların anestezi memnuniyetinin ve anestezi bilgilerinin değerlendirilmesi. Gaziosmanpaşa Üniversitesi Tıp Fakültesi Dergisi 2013; 5(2): 84-90. 